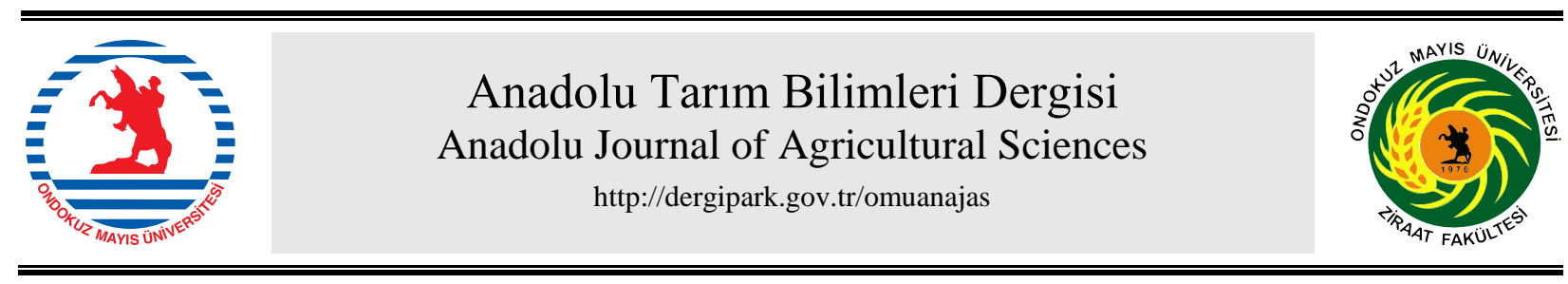

Araştırma/Research

Anadolu Tarım Bilim. Derg./Anadolu J Agr Sci, 33 (2018)

ISSN: 1308-8750 (Print) 1308-8769 (Online) doi: $10.7161 /$ omuanajas.412040

\title{
Arazi toplulaştırma projelerinde başarının değişik göstergelere göre değerlendirilmesi
}

\author{
Metin Akdeniz $^{\mathrm{a}}$ Kadir Ersin Temizel ${ }^{\mathrm{b}^{*}}$ \\ ${ }^{a}$ Samsun İl Gıda Tarım ve Hayvancllık Müdürlügü, Samsun \\ ${ }^{b}$ Ondokuz Mayıs Üniversitesi Ziraat Fakültesi, Tarımsal Yapılar ve Sulama Bölümü, Samsun \\ "Sorumlu yazar/corresponding author: ersint@omu.edu.tr
}

Geliş/Received 02/04/2018 Kabul/Accepted 24/05/2018

\begin{abstract}
ÖZET
Bu çalışma Tarım Reformu Genel Müdürlüğü (TRGM) tarafından projesi yürütülen Samsun ili, Bafra İlçesine bağlı 20 mahallede, Amasya ili Merkez ilçeye bağlı 10, Göynücek İlçesinde 2, Gümüşhacıköy ilçesinde 10 köyde, Sinop ili Boyabat İlçesinde 14, Durağan ilçe merkezi ve 3 köyde olmak üzere toplam 60 proje sahasında yapılan toplulaştırma projelerinde başarının değişik kriterlere göre değerlendirilmesi ve bunda yeni bir bakış açısı ortaya konulması amacıyla yapılmıştır. Başta parsel sayısı üzerinden toplulaştırma oranı (TO) olmak üzere toplam 17 parametre bakımından projelerin öncesi ve sonrası durumları ortaya çıkarılmıştır. Bu çalışma kapsamında toplulaştırmadan tam anlamıyla başarı elde etmek için farklı kriterler incelenmiş ve bazı yeni kriterler ile performans değerlendirilmesi yapılmıştır. Bunun için Samsun, Sinop ve Amasya illerindeki 6 ilçede, 60 köy/mahalleyi kapsayan arazi toplulaştırma projelerindeki bilgiler kullanılmıştır. Çalışma sonucunda TO ile ortalama parsel büyüklügünün $(\mathrm{OBP})$ toplulaştırma öncesi ve sonrasına oranı arasında $\mathrm{TO}=-$ 72.013 x OPB + $86.587\left(\mathrm{R}^{2}=0.92\right)$ şeklinde bir ilişki bulunurken bir biri ile en yüksek korelasyon sırasıyla Malike Düşen Ortalama Parsel Adedi (MDOPA), Parsellerin Köy Merkezine Uzaklığı Toplamı (PKMUT),Toplulaştırma oranı (TO), Birim Alan Kaybı (BAK), Parsel Çevreleri Toplamı (PÇT), Tam Parsel Sayısı (TPS), Birim Çevre (BÇ), Ortalama Parsel Büyüklüğü (OPB), Parsel Büyüklüğü Sayısı (PBS), Tam Parseldeki Malik sayısı (TPMS), Parseldeki Maliklerin Köy Merkezine Uzaklı̆̆ı Toplamı (MKMUT), Malike Düşen Ortalama Hisse Sayısı (MDOHS), Maliklerin Parsel Durumu (MPD), Tam Parsel Alanı (TPA), Parsellerin Nokta Sayısı Toplamı (NST) parametrelerinde ortaya çıkarken en az ilişki ise Hisse Sayısı Üzerinden Toplulaştırma Oranı (HSTO) parametresinde ortaya çıkmıştır.
\end{abstract}

Evaluation of success in land consolidation projects by different indicators

\footnotetext{
ABSTRACT

This study was carried out in 20 neighborhoods of Samsun province at Bafra district, 10 villages of Centre of Amasya province, 2 villages in Göynücek district, 10 villages in Gümüşhacıköy district, 14 villages of Sinop province at Boyabat district, 1 village in center of district and 3 villages in Durağan district. In order to evaluate the success of the consolidation projects, a total of 60 projects was performed by taking into consideration of different criteria. In addition to that, in this research it was also aimed to put a new approach about this area. Mainly the Consolidation Ratio (TO) based on the number of plots and previous and after of project status were determined in terms of a total of 17 parameters. Within the concept of this study, different criteria were examined in order to achieve success in consolidation studies and performance evaluation was also made with some new criteria. For this purpose, some data for the land consolidation projects covering 60 villages / neighborhoods were used for 6 districts of Samsun, Sinop and Amasya provinces. As a result of the study, the relationship between TO and the ratio of the average Plot size (OBP) before and after consolidation study was found as TO $=-72.013 \times \mathrm{OPB}+86.587\left(\mathrm{R}^{2}=0.92\right)$, while the highest correlation was found between Average Plot Number Per Owner (MDOPA), Total of Distances to Center of the Village to the Every Plots (PCMUT), Consolidation Rate (TO), Unit Area Loss (BAK), Total Plot Perimeter (PÇT), Number of Plots with Single Owner (TPS), Unit Perimeter (BÇ) and Average Plot Size (OPB), The Number of Plots According to Field Size Ranges (PBS), The Number of Owners in Single-Owned Plots (TPMS), The Total Distance of Every Owners in Every Plots to Center of the Village (MKMUT), The Average
}

Anahtar Sözcükler: Arazi toplulaştırması Arazi toplulaştırma başarı kriterleri Toplulaştırma oranı

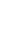


Number of Shares for Per Owners (MDOHS), The Plots Number Status for Owners (MPD), The Total Area of Single-Owned Plots (TPA), The Total Number of Corner Points in Plots (NST) respectively. Moreover, it was detected the lowest relation between Consolidation Ratio and The Consolidation Ratio C OMU ANAJAS 2018 in Terms of Number of Shares (HSTO)

\section{Giriş}

Artan nüfus ve beslenme ihtiyac1, daha fazla tarımsal ürün elde etme gereği doğurmuştur. Toprak kaynaklarının sınırlı olması nedeniyle, aynı alandan daha fazla ürün elde etme imkânlarının aranması gerekmektedir.

Dünyadaki nüfus artışına bağlı olarak, günümüzde bazı ülkelerde görülen ve gelecekte diğer ülkelerde de ortaya çıkma riski bulunan açlık sorunu, toplumları tedirgin etmektedir. Bu tedirginlik bir yandan mevcut ekilebilir alanlarda üretimi artırıcı yeni tekniklerin uygulanmasını, diğer yandan ise bugün için verimsiz kabul edilen toprakların da üretime açılarak, tarımsal ürün üretim hacminin artırılmasını mümkün hale getirmiştir. Böylece tarımsal üretim teknolojilerinin artırılması sonucu, mevcut üretimi 5-6 kat çoğaltmak mümkün olabilmektedir (Bayraç ve Yenilmez, 2006).

Ülkemizde nüfusun Türkiye İstatistik Kurumu 2013 verilerine göre \% 6.08'si belde ve köylerde yaşamaktadır. Köylünün temel üretim aracı topraktır. Köylünün tarımsal üretim yaptığı parsellerin büyüklüklerinin küçük olması ve ayrıca miras nedeniyle daha küçük parçalara bölünmesi nedeniyle tarım toprakları verimli biçimde işlenemeyecek duruma gelmeye devam etmektedir. Gida Tarım ve Hayvancılık Bakanlığı 5403 sayılı kanun ile arazi ve toprak kaynaklarının bilimsel esaslara uygun olarak belirlenmesi, sinıflandırılması, arazi kullanım plânlarının hazırlanması, koruma ve geliştirme sürecinde toplumsal, ekonomik ve çevresel boyutlarının katılımcı yöntemlerle değerlendirilmesi, amaç dışı ve yanlış kullanımların önlenmesi, korumayı sağlayacak yöntemlerin oluşturulmasına yönelik gerekli yasal düzenlemeyi yapmıştır.

Toplulaştırma çalışmaları ile ilk planda tarımın geliştirilmesi ve tarımsal ürünlerin miktar ve kalite yönünden artırılması, tarımda iş gücünü ekonomikleştirme ve nihayet tarımsal işletmelerin net gelirlerinin yükseltilmesi amaçlanmaktadır (Arıcı, 1994; Arslan ve Tunca, 2013).

İşletmelerin sahip olduğu arazi büyüklüklerinin yetersiz olması, işletmelerde ulaşım ve taşıma kayıplarını, dolayısıyla maliyeti arttırmaktadır. Bunun sonucunda çiftçiler arazilerine gereken önemi verememekte, modern girdileri uygulayacak ortam bulamamakta ve sermaye birikimini yaratamamaktadır. Belirlenen yapı içerisindeki bu işletmelerde yer alan arazi parçalarına yol, su, drenaj ve tesviye gibi altyapı hizmetleri güçleşmekte ve maliyeti de yüksek olmaktadır (Ekinci, 2012).

Boyraz ve Üstündağ (2008), yaptığ 1 çalışmada arazi toplulaştırma çalışmalarının kırsal alanın sosyoekonomik sorunlarına ve tarımsal faaliyetlere çözüm getirmesi bakımından da büyük önem taşıdığını belirtmiştir. Toplulaştırmanın kırsal alanda çalışma ve üretim koşullarının iyileştirilmesi, tarımsal üretimde çalışanların gelir seviyelerinin ve yaşam koşullarının iyileştirilmesi, tarımsal işgücünün tam verimi kullanılması ve köyden kente göç olaylarını yavaşlatmak için kırsal alan planlaması olduğu belirtilmiştir. Toplulaştırma ile yol, sulama ve drenaj kanallarından herkesin eşit oranda faydalanması sağlanmaktadır.

Takka (1988), Balıkesir-Sındırgı İbiller köyünde yapılan arazi toplulaştırması projesi ile sulamadan faydalanma oranının $\% 19$ 'dan $\% 83.5$ 'e ve drenajdan faydalanma oranının \% 33.4'den \% 100'e çıktığını belirlemiştir. Aynı çalışmada, Tokat-Erbaa-Çalkara arazi toplulaştırması projesinde; toplulaştırma öncesi durumda sulamadan faydalanma oranı \% 6 iken, toplulaştırma projesi sonrasında ise sulama ve drenajdan faydalanma oranı \% 100'e ulaştı̆̆ını belirlemiştir.

Boyacıoğlu, (1973) çalışmasında toplulaştırmada parsel sayısının azalması, parsel büyüklüğünün artması ve işletme merkezi ile parseller arası mesafe ve yol standardının değişmesi sonucu, işgücünde her parsel için 2.5 saat/da tasarruf sağlanırken makine kullanım veriminin, her parselde 0.5 saat da-1 arttığını belirtmiştir.

Devlet Planlama Teşkilatı III. Beş Yıllık Kalkınma Planında yer alan Arazi Kullanımı, Arazi ve Arsa Politikaları ve Arazi Toplulaştırması Alt Komisyonu Raporunda, günümüzde geniş kapsamlı bir arazi toplulaştırması çalışması tarla şekillerinin iyileştirilmesi, çiftçinin çalışma ve üretim koşullarının iyileştirilmesi, tarımsal üretimde çalışanların gelir seviyeleri ve yaşam koşullarının iyileştirilmesi, tarımsal işgücünün tam verimi kullanılması için gerekli hizmetleri ve yatırımları kapsaması gerektiği belirtilmiştir (Anonim, 2000).

Arazi toplulaştırmasında projeler tamamlandığında projenin performansını gösteren herhangi bir değerlendirme yapılmamaktadır. Ancak bazı çalışmalarda sadece toplulaştırma oranları hesaplanmaktadır.

Toplulaştırma projeleri incelendiğinde aynı proje içerisindeki köylerde bile çok farklı sonuçların elde edildiği görülmektedir. $\mathrm{Bu}$ çalışma kapsamında toplulaştırma projelerin performansını değerlendirmek için analiz ve değerlendirme yönteminde belirtilen 17 kriter incelenmiş ve bu yeni kriterler doğrultusunda performans değerlendirilmesi yapılmıştır.

Bunun için Samsun, Sinop ve Amasya illerinde 6 ilçede $60 \mathrm{köy} /$ mahalleyi kapsayan arazi toplulaştırma projesindeki bilgiler kullanılmıştır. 


\section{Materyal ve Yöntem}

\subsection{Materyal}

Bu çalışmada, Tarım Reformu Genel Müdürlüğü tarafindan ihale edilen Samsun, Amasya ve Sinop illerindeki toplam 244699 da alanda 24429 maliki bulunan 60 mahalle/köyde yapılan arazi toplulaştırma ve tarla içi geliştirme hizmetleri projeleri kullanılarak elde edilen verilerden yararlanılmıştır.

Araştırma, Samsun ili Bafra ilçesinde yer alan Yağmurca, Çetinkaya, Kaygusuz, Emenli, Koruluk, Fener, Altınay, Adaköy, İkiztepe, Harız, Hüseyinbeyli, Kalaycıllı, Karaburç, Kelikler, Kuşçular, Sahilkent, Şirinköy, Dedeli, Örencik ve Yörgüç mahallesi olarak toplam 20 mahallede arazi toplulaştırması yapılan 6214 parsel 14000 ha alan ve 10203 maliki kapsamaktadır.

Amasya ilinde ise merkez ilçeye bağlı Akyazı, Aydoğdu, Bağlıca, Doğantepe, Gözlek, Kayabaşı, Ovasaray, Toklucak, Tuzsuz ve Kutu köyleri ve Göynücek ilçesindeki Bektemur ve Konuralan köyleri olmak üzere toplam 12 kırsal yerleşimde arazi toplulaştırması yapılan 74648 da alan, 5705 parsel ve 4818 maliki kapsamaktadır. Amasya ili Gümüşhacıköy ilçesinde yer alan Çavuşköy, Çetmi, Doluca, Eslemez, Keçiköy, Kiziroğlu, Karacaören, Sallar, Yaziyeri ve Güblüce köylerinde arazi toplulaştırması yapılan 42507 da alanda 4574 parsel ve 3463 maliki kapsamaktadır.

Sinop İli Boyabat ilçesinde yer alan Cemalettin, Tekke, Daylı, Yabanl,, Edil, Gazidere, Ilıca, İmamlı, Salar, Osman, Okçumemetli ve Kayaboğazı köylerinde Durağan ilçelerinde yer alan Yalnızkavak, Yeşilkent, Aşağıkaracaören, İncir, Yandak ve Durağan Merkez ilçede arazi toplulaştırması yapılan 23940 da alan, 13958 parsel ve 5945 maliki kapsamaktadır.

\subsection{Yöntem}

\subsubsection{Analiz ve Değerlendirme Yöntemi}

Proje sahasındaki verilerin hesaplanmasında yada elde edilmesinde toplulaştırma öncesindeki ile toplulaştırma sonrasındaki veriler kullanılmıştır. Toplulaştırmadan önceki ve sonraki verilerin işığında yeni veriler üretilmiştir. $\mathrm{Bu}$ veriler üretilirken her köy/mahalledeki projeye giren parsellerin ve maliklerin durumları aşağıda belirtilen 17 parametreye göre değerlendirilmiştir.

Arazi toplulaştırması ve tarla içi geliştirme hizmetleri yapılan köy/mahallelerde aşağıda sıralanan arazi toplulaştırma projelerin değerlendirilmesinde en etkili olabileceği düşünülen parametreler dikkate alınarak belirlenmiştir. Bunlar sırasıyla; Parsel Sayısı Üzerinden Toplulaştırma Oranı (TO), Hisse Sayısı Üzerinden Toplulaştırma Oranı (HSTO), Tam Parsel Sayısı (TPS), Tam Parsel Alanı (TPA), Tam Parseldeki Malik Sayısı (TPMS), Parsel Çevreleri Toplamı (PÇT), Parsellerin Köy Merkezine Uzaklığı Toplamı (PKMUT), Parseldeki Maliklerin Köy Merkezine
Uzaklığı Toplamı (MKMUT), Parsellerin Nokta Sayısı Toplamı (NST), Maliklerin Parsel Durumu (MPD), Ortalama Parsel Büyüklüğü (OPB), Malike Düşen Ortalama Parsel Adedi (MDOPA), Malike Düşen Ortalama Hisse Sayısı (MDOHS), Parsel Büyüklüğü Sayısı (PBS), Birim Çevre (BÇ), Birim Alan Kaybı (BAK), Projelerin Performans Değerleri ve Parametrelerin Arasındaki Korelasyon Değerleri (PAKD) verileri kullanılmıştır.

1. Parsel Sayısı Üzerinden Toplulaştırma Oranı (TO), Hisse Sayısı Üzerinden Toplulaştırma Oranı (HSTO)

$$
\text { TO }=\frac{\text { EPS-YPS }}{\text { EPS }} \times 100 \quad \text { ile HSTO }=\frac{\text { EHS-YHS }}{\text { EHS }} \times 100
$$
hesaplanmaktadır.

Denklemlerde; EPS: Eski parsel sayıs1 (adet), YPS: Yeni parsel sayısı (adet), EHS: Toplulaştırma öncesi hisse sayısı (adet), YHS: Toplulaştırma sonrası hisse sayıs1 (adet)

2. Tam Parsel Sayısı (TPS), Tam Parsel Alanı (TPA), Tam Parseldeki Malik Sayısı (TPMS)

Tam parsel sayısı parsellerdeki mülkiyetlerin tek malikli olması durumuna tam parsel denir. Tam parsel alanı tüm tek malikli parsellerin toplam alanını ifade eder. Tam parsellerdeki malik sayısını ise tüm parsellerdeki maliklerin müstakil olanların sayısını ifade eder.

\section{Parsel Çevreleri Toplamı (PÇT)}

Parsellerin diş kenarlarının uzunluğunu ifade eder. Her bir parselin çevre uzunluğu bulunarak tüm proje alanındaki parsellerin çevrelerin toplamının bulunmasidir.

Ç: Çevre uzunluğu (m), $\mathrm{n}$ parsel sayısı, $\mathrm{PÇT}=\sum_{1}^{\mathrm{n}} \mathrm{C}$ şeklinde bulunur.

4. Parsellerin Köy Merkezine Uzaklığı Toplamı (PKMUT), Parseldeki Maliklerin Köy Merkezine Uzaklığı Toplamı (MKMUT)

PKMUT'nı hesaplamak için; Parsellerin ağırlık merkezi ile köy merkezindeki bir nokta arasındaki kuş uçuşu mesafelerin toplamıdır.

MKMUT ise parsellerin ağırlık merkezinin köy merkezindeki bir noktaya kuş uçuşu mesafesinin parseldeki malik sayısıyla çarpımıyla elde edilir.

\section{Parsellerin Nokta Sayısı Toplamı (NST)}

Parsellerin dış kenar sınırının her kırık noktasının tek tek sayılmasıly elde edilir. 


\section{Maliklerin Parsel Durumu (MPD)}

Proje alanı maliklerinin kaç parselde mülkiyeti olduğunu ifade eder. Maliklerin parseldeki mülkiyeti (1), (2-3), (4-5), (6-9) ve (10+) olarak 5 grupta değerlendirilmiştir. Buna göre tüm proje alanında (1) tek hissesi olan malik sayısını, (2-3) proje alanında 2-3 hissesi olan malik sayısını, (4-5) proje alanında 4-5 hissesi olan malik sayısını gösterecek şekilde düzenlenmesidir. Bunların toplamı ise proje alanındaki malik sayısını vermektedir.

\section{Ortalama Parsel Büyüklüğü (OPB)}

Proje alanının dekar olarak büyüklüğünün parsel sayısına bölünmesiyle elde edilir (Boztoprak ve ark., 2016).

\section{Malike Düşen Ortalama Parsel Adedi (MDOPA)}

Proje sahasındaki parsel sayısının malik sayısına bölünmesiyle elde edilir.

\section{Malike Düșen Ortalama Hisse Sayısı (MDOHS)}

Proje alanı toplam hisse sayısının çalışma alanında malik sayısına bölünmesiyle bulunur.

\section{Parsel Büyüklüğü Sayısı (PBS)}

Proje sahasındaki parsellerin da (dekar) bazında büyülüğünü ifade eder. (0-1), (1-2), (2-5), (5-10), (10$25), \quad(25-50)$ ve $(50+)$ olarak 7 grupta değerlendirilmiştir. Buna göre tüm proje alanında $(0-1)$ 1 da'da dahil olan parsellerin sayısını, (1-2) proje alanında 1 da ile 2 da dahil olan parsellerin sayısını, (25) proje alanında 2 da ile 5 da dahil olan parsellerin sayısını, (5-10) proje alanında 5 da ile 10 da dahil olan parsellerin sayısını, (10-25) proje alanında 10da ile 25 da dahil olan parsellerin sayısını, (25-50) proje alanında 25 da ile 50 da dahil olan parsellerin sayısını, $(50+)$ proje alanında 50 da dan daha büyük olan parselleri sayısını gösterecek şekilde düzenlenmesidir.

\section{Birim Çevre (BÇ)}

Parsel Çevreleri Toplamını (PÇT) Proje alanının metrekare olarak büyüklügünün bölünmesiyle bulunur.

\section{Birim Alan Kayb1 (BAK)}

Proje alanındaki parsellerin çevreleri boyunca $50 \mathrm{~cm}$ genişliğinde bir kısımda ekim dikim zorluğu olduğu bilinir. Bu nedenle bu kısma kayıp alan denilir. Proje sahasındaki tüm parsellerin kayıp alanları PÇT'yi $0.5 \mathrm{~m}$ genişliğiyle çarpılarak bulunur. Tüm proje sahası için bu alanların toplamı proje sahası için kayıp alan miktarını ortaya çıkarır. Bu kayıp alan miktarının $\left(\mathrm{m}^{2}\right)$ toplam alana (da) bölünmesiyle de birim alan kaybı bulunur.

\section{Parametrelerin Arasındaki Korelasyon Değerleri} (PAKD)

Proje alanında 60 köy/mahalle incelenen parametreler için Microsoft Office Excel program yardımıyla korelasyonlar bulunur. Çalışmada bu parametrelerden TO ve HSTO \%'lik oran olduğundan doğrudan alınmış TPS, BÇ, PÇT, TPA, TPMS, BÇ, PKMUT, MKMUT, NST, OPB, MDOPA, MDOHS ve BAK değerleri ise toplulaştırma öncesi değerinin toplulaştırma sonrası değerine bölümüyle bulunan oran ile hesaplanmıştır. PBS ise toplulaştırma öncesinin (0$1),(1-2), \quad(2-5), \quad(5-10), \quad(10-25), \quad(25-50)$ ve $(50+)$ değerlerinin toplulaştırma sonrası değerine bölünerek oluşan değerler toplanarak bulunan oran ile hesaplanmıştır. MPD ise toplulaştırma öncesi (1), (2-3), (4-5), (6-9) ve (10+) değerlerine toplulaştırma sonrasındaki değerlere bölünmesiyle oluşan değerlerin toplamıyla bulunan oran ile bulunmuştur.

\section{Projelerin Performans Değerleri}

Proje alanında performansı değerlendirebilmek için TO, HSTO, TPS, TPA, TPMS, PÇT, PKMUT, MKMUT, NST, MPD, OPB, MDOPA, MDOHS, PBS ve $B C ̧$, değerlerinin toplulaştırma öncesi ile toplulaştırma sonrası dikkate alınarak olumlu veya olumsuz oluşuna göre değerlendirilmiştir. Olumlu olan değerlere 1 değeri verilirken olumsuzlara 0 değeri verilmiştir. TO ve HSTO pozitif olanlara 1 negatif olanlara 0 değeri, TPS, TPA ve TPMS değerlerinde toplulaştırmadan önceki yüzde durumunun toplulaş̧ırma durumuna göre artış olduğunda 1 , azalış olduğunda 0 , OPB değerlerinde ise toplulaştırma öncesine göre artış olduğunda 1 değeri, azalma olduğunda 0 değeri, MDOPA, MDOHS, PÇT, PKMUT, MKMUT, NST ve $\mathrm{BÇ}$ değerinde azalma olduğunda 1 , artış olduğunda 0 değeri verilmiştir. PBS değerini olumlu ve olumsuz değerlendirilmesi için 0-1 da, 1-2 da, 2-5 da ve 5-10 da aralığındaki toplulaştırmadan önceki yüzde durumunun toplulaştırma sonrasındaki yüzde durumuna göre azalma olduğunda 1 , artış olduğunda 0 değeri, $10-25,25-50$ ve $50+$ dekarda artış olduğunda 1 , azalma olduğunda 0 değeri verilmiştir. MPD değerini olumlu ve olumsuz değerlendirilmesi için de toplulaştırmadan önceki yüzde durumunun toplulaştırma sonrasındaki yüzde durumuna göre 1 parsel ve 2-3 parsel aralığındaki değerlerde artı̧̧ olduğunda 1 , azalma olduğunda 0 değeri, 4-5 parsel, 6-9 parsel ve $10^{+}$parsel aralığındaki durumunda azalma olduğunda 1 , artış olduğunda 0 değeri verilmiştir.

\section{Bulgular ve Tartışma}

\subsection{Parsel Sayısı Üzerinden Toplulaştırma Oranı (TO), Hisse Sayısı Üzerinden Toplulaştırma Oranı (HSTO)}

Proje alanındaki incelenen 60 köy/mahallede parsel sayıs1 üzerinden toplulaştırma oranı $\%-81.88$ ile $\%$ 76.70 arasında değerler almıştır. $13 \mathrm{köy} /$ mahallede toplulaştırma oranı eksi değer alırken 47 köy/mahallede 
ise artı değerler almıştır. Parsel sayıları üzerinden yapılan toplulaştırma oranı ortalama parsel büyüklüğü yüksek olan köy/mahallelerde maliklerin parsellerde hisseli olan arazilerini müstakil tercih etmelerinden dolayı parsel sayısında artış oluştuğundan toplulaştırma oranı eksi çıkmaktadır.

İncelenen $60 \mathrm{köy} /$ mahallede hisse sayısı 2 mahallede toplulaştırma önceki duruma göre toplulaştırma sonrasında artış göstermiş olduğundan 2 birimde hisse sayısı üzerinden toplulaştırma oranı negatif değer almış olup, geri kalan $58 \mathrm{köy} /$ mahallede ise toplulaştırma sonrasında hisse sayısında azalma olduğundan pozitif olmuştur. Şekil 1'de 59 projedeki TO ve HSTO arasındaki ilişkinin grafiği gösterilmiştir. Grafikte gösterilmeyen Emenli mahallesinde hisse sayıs1 üzerinden toplulaştırma oranı \%-1115.4 olduğundan grafikten çıkarılmıştır.

Parsel sayısı üzerinden toplulaştırma oranı negatif ve pozitif değerler almıştır. Maliklerinin proje sahasındaki parsellerdeki tüm hisselerini bir araya getirerek daha kullanılabilir parseller oluşturması, hisse sayısı üzerinden toplulaştırma oranını özel durumlar dışında pozitif değerler almasını sağlamaktadır. TO projeyi yürüten birim için iyi bir gösterge olabilir ancak arazi malikleri için HSTO daha iyi bir gösterge olmaktadır.

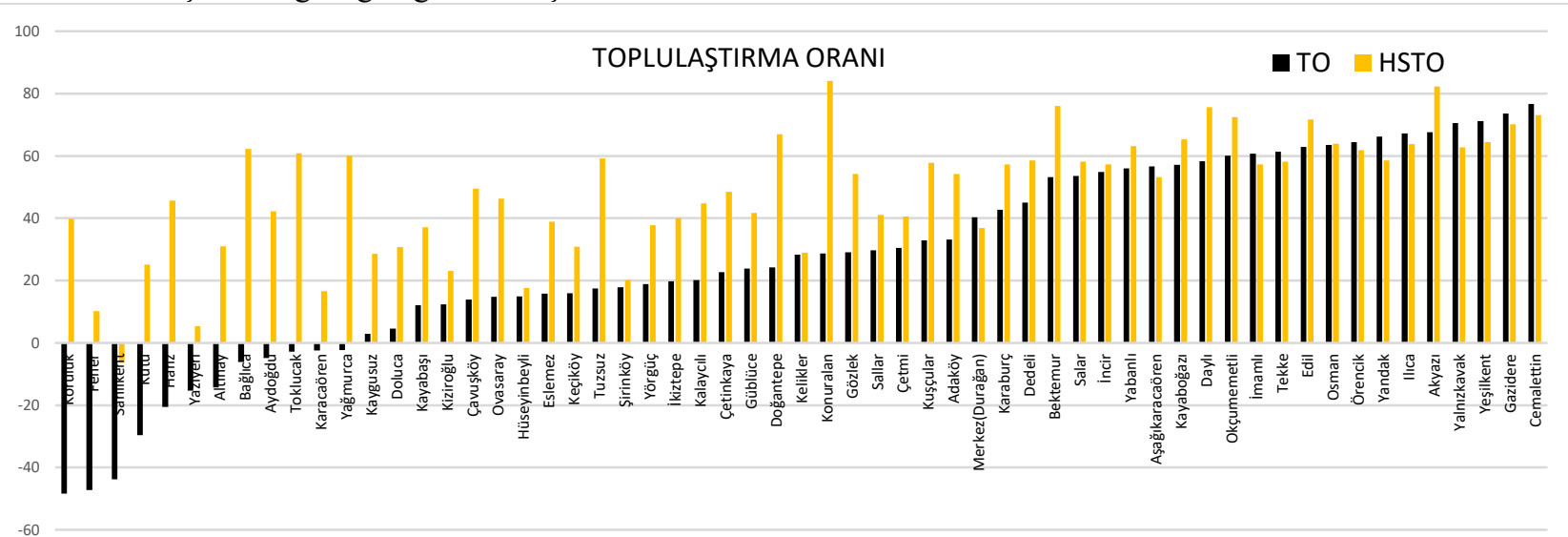

Şekil 1. Projedeki köylerin TO ve HSTO değerleri

\subsection{Tam Parsel Saylsı (TPS), Tam Parsel Alanı (TPA),} Tam Parseldeki Malik Saylsu (TPMS)

Proje alanında 60 köy/mahalleye ait tam parsel sayısı, tam parsel alanları toplamı ve tam parseldeki malik sayısı Çizelge 1'de incelenmiştir. İncelenen 60 projede TPS sayısinda \% 35.78 azalma, TPA'da $\% 18.53$ artış ve TPMS'da \% 8.91 artış meydana gelmiştir.

İncelenen projelerden 36 tanesinde TPS ortalama $\% 42.2$ düşüş, diğerlerinde ortalama $\% 49.4$ artış, TPA 26 tanesinde $\% 17.9$ düşüş, geri kalanında $\% 34$ artış, TPMS de ise 23 projede ortalama \% 24.4 düşüş görülürken diğerlerinde \% 63 artış gözlenmiştir (Şekil 2).

Çizelge 1. Projedeki TPS, TPA, TPMS ve \% değişim durumu

\begin{tabular}{|c|c|c|c|c|c|c|c|c|c|}
\hline & \multicolumn{3}{|c|}{ Toplulaştırma Öncesi } & \multicolumn{3}{|c|}{ Toplulaştırma Sonrası } & \multicolumn{3}{|c|}{ \% Değişim } \\
\hline & TPS & TPA(da) & TPMS & TPS & TPA(da) & TPMS & TPS & TPA & TPMS \\
\hline Toplam & 19117 & 113235 & 7276 & 12276 & 134212 & 7924 & -35.78 & 18.53 & 8.91 \\
\hline
\end{tabular}

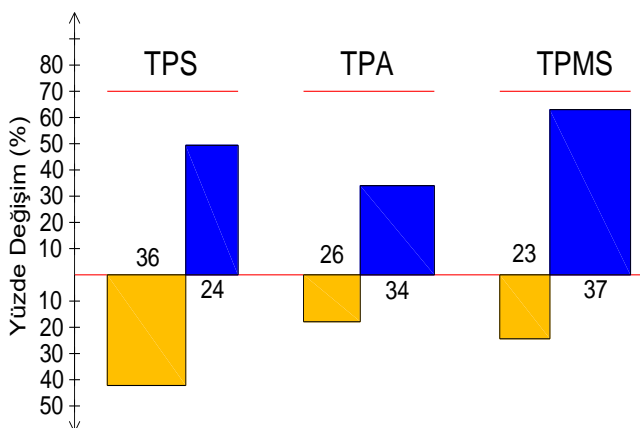

Şekil 2. Proje alanındaki incelenen projelerdeki tam parsel, alanları ve malik sayıları değişim oranları 
TPS, TPA ve TPMS özellikleri birlikte dikkate alındığında her biri için tüm projelerde artışın daha fazla olduğu görülmektedir (Şekil 3).

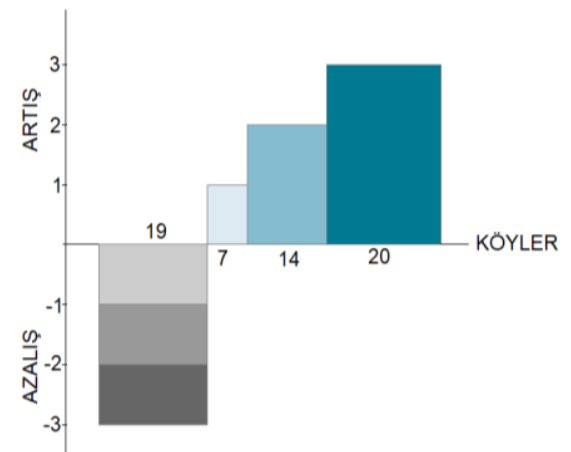

Şekil 3. İncelenen Projelere ait TPS, TPA ve TPMS parametrelerin artış ve azalış grafiği

Tam parsel sayısı, tam parsel alanı ve tam parselli malik sayısında her üç parametre dikkate alındığında 20 tane proje alanında artış olduğu, 14 tane proje alanında iki parametrede artış olduğu, 7 tane proje alanında bir parametrede artış olduğu, 19 birimde de TPS, TPA ve TPMS de azalış meydana gelmiştir.

\subsection{Parsel Çevreleri Toplamı (PÇT)}

Proje alanında 60 köy/mahalleye ait parsel çevreleri toplamı Şekil 4'de gösterilmiştir. Tarım yapılan alanlarda çit veya tarla sınırına yaklaşamama nedeniyle, tarla sınırına paralel en az $50 \mathrm{~cm}$ genişliğindeki bir tarla şeridi tam anlamıyla ekilemediği varsayılır. Bu ise bir kısım alanın boş kalmasına veya ürün kaybına neden olur.

Şekil 4'de incelenen $60 \mathrm{köy} /$ mahallenin 43 köy/mahallede parsel çevre toplamında azalma olmuş 17 köy/mahallede de artma olmuştur. Artma olan bu köy/mahalleler incelendiğinde ortalama parsel büyüklük değeri yüksek olan köy/mahalleler olup büyük parsellerin birden çok parsele bölünmesiyle parsel çevresinde artı̧̧ meydana gelmiştir.

Araştırma yapılan 60 köy/mahalledeki 30475 parselin toplam çevre uzunluğu toplulaştırmadan öncesi 9994307 m iken toplulaştırma sonrasında \%11 oranında azalmayla $8888062 \mathrm{~m}$ olmuştur. $60 \mathrm{köy} /$ mahallede toplulaştırma öncesiyle sonrası arasındaki çevre toplamı fark1 $1106244 \mathrm{~m}$ dir.

\subsection{Parsellerin Köy Merkezine Uzakliğ Toplamı (PKMUT), Parseldeki Maliklerin Köy Merkezine Uzaklı̆̆ı Toplamı (MKMUT)}

Proje alanında köy/mahalleler incelendiğinde proje sahasındaki 30475 parsele yalnızca parsellerdeki bir malikin köy merkezinden kuş uçuşu olarak yalnızca bir defa gitmek için $41818 * 2=83636 \mathrm{~km}$ yol kat etmesi gerekmekteydi. Toplulaştırma sonrasında ise yalnızca parsellerdeki bir malikin köy merkezinden kuş uçuşu olarak yalnızca bir defa gitmek için $26868 * 2=53736 \mathrm{~km}$ yol kat etmesi gerekmektedir. İncelenen 60 köy/mahalledeki yol kazancı yalnızca bir malikin parsele ulaşması sonucunda $83636-53736=29900 \mathrm{~km}$ olmaktadır.

Proje sahasında toplulaştırma öncesinde 94788 hisse olduğundan her parseldeki malik sayısını parselin merkeze uzaklı̆̆ıyla çarptığımızda maliklerin köy merkezinden kuş uçuşu olarak yalnızca bir defa gitmek için $145794 * 2=291587 \mathrm{~km}$ yol kat etmesi gerekmekteydi. Toplulaştırma sonrasında ise parsellerdeki bir maliklerin parsellerine köy merkezinden kuş uçuşu olarak yalnızca bir defa gitmek için $93797 * 2=187594 \mathrm{~km}$ yol kat etmesi gerekmektedir. İncelenen $60 \mathrm{köy} /$ mahallede yol kazancı 291587$187594=103993 \mathrm{~km}$ olmaktadır.

\subsection{Parsellerin Nokta Sayısı Toplamı (NST)}

Proje alanında 60 köy/mahalleye ait parsellerin nokta sayısı toplamı toplulaştırmadan önce 217739 adet iken toplulaştırmadan sonra 102371 adet olmuştur.

60 proje incelendiğinde her bir proje için parsel başına düşen eski ve yeni nokta sayıları belirlenmiştir. Belirlenen bu değerlerden dörtgenin köşe sayısı olan 4 sayısı çıkarılarak oluşturulan mutlak farkların 60 proje için toplamı önce 4.84, sonrasında ise 1.94 olarak hesaplanmıştır. $\mathrm{Bu}$ ise 4' e kadar yaklaşıldığını göstermektedir. 60 projede 4'e yaklaşım oranı $\% 40$ olarak belirlenmiştir.

\subsection{Maliklerin Parsel Durumu (MPD)}

Proje alanında 60 köy/mahalleye ait maliklerin parsel durumu Çizelge 2'de gösterilmiştir.

Çizelge 2 incelendiğinde toplulaştırma öncesinde proje alanındaki 24429 malikin 10871 'i nin parsellerde 1 hissesi bulunmakta, 2 ve 3 hissesi bulunan 6351 malik, 4 ve 5 hissesi bulunan 2715 malik, 6 ve 9 hissesi bulunan 2281 malik, 10 ve üstü hissesi bulunan 2211 malik bulunmaktadır. Toplulaştırma sonrasında ise 1 hissesi bulunan 16467 malik, 2 ve 3 hissesi bulunan 5805 malik, 4 ve 5 hissesi bulunan 1206 malik, 6 ve 9 hissesi bulunan 379 malik, 10 ve üstü hissesi bulunan 572 (\% 2.34) malik bulunmaktadır.

Toplulaştırma öncesi ve sonrası parsellerde hissesi bulunan köy/mahalledeki malik sayısının tüm malik sayısına göre yüzdelik durumu Çizelge 3'de gösterilmiştir. Toplulaştırma öncesinde 1 hissesi bulunan malikler ortalama \% 44.50 iken toplulaştırma sonrasında $\% \quad 67.41$ olmuş, 2-3 hissesi olanlar toplulaştırma öncesinde \% 26, toplulaştırma sonrasında \% 23.76 olmuş, 4-5 hissesi olanlar toplulaştırma öncesinde \% 11.11, toplulaştırma sonrasında \% 4.94 olmuş, 6-9 hissesi olanlar toplulaştırma öncesinde \% 9.34, toplulaştırma sonrasında $\% 1.55$ olmuş, 10 ve üstü hissesi olanlar toplulaştırma öncesinde \% 9.05, toplulaştırma sonrasında \% 2.34 olmuştur. Şekil 5'de 1 hissesi bulunan maliklerin toplulaştırma öncesinde ve 
toplulaştırma sonrasında \%’lik değişim grafiğ i gösterilmiştir.

\subsection{Ortalama Parsel Büyüklüğü (OPB)}

60 köy/mahallesinin 43'ünde OPB oranında artış meydana gelmiş geri kalan 17 köy/mahallede OPB oranında azalma meydana gelmiştir. Azalma parselleri büyük olan köy/mahallelerde meydana gelmiştir. OPB azalma olan 17 köy/mahallenin 13'ünde parsel sayısina göre toplulaştırma oranı eksi çıkan köy/mahallelerden 4 tanesi artı çıkan köy/mahallelerdendir. Şekil 6 da OBP nin TÖ'ne göre yüzdelik değişim grafiği verilmiştir.

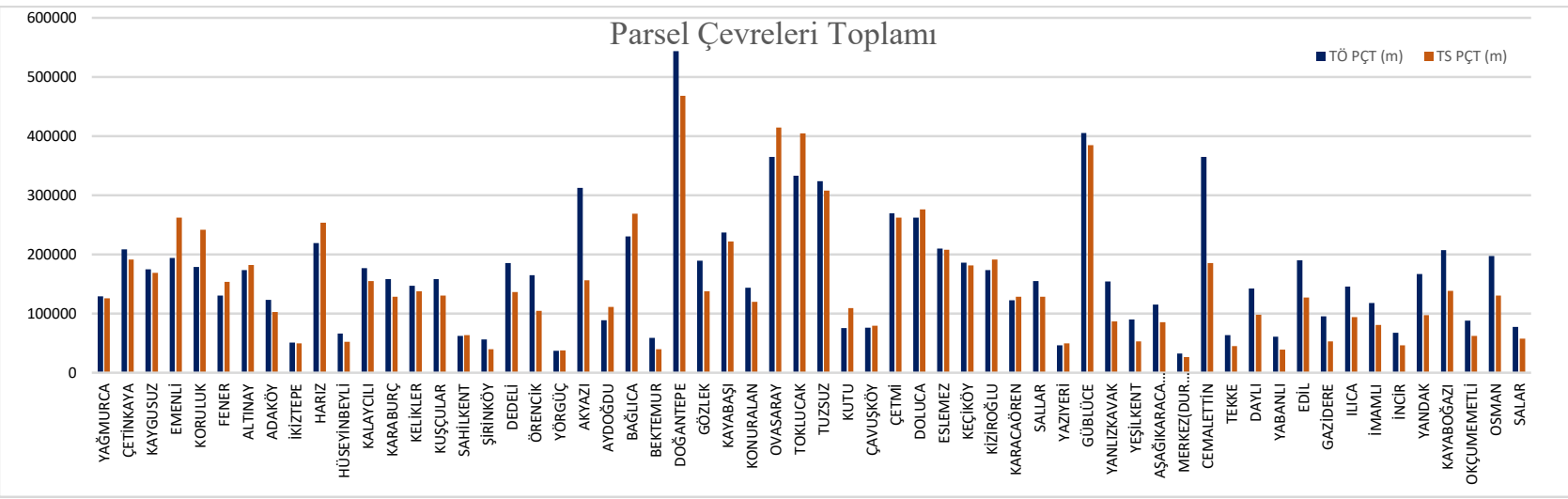

Şekil 4. İncelenen Projelere ait toplulaştırmadan önce ve sonraki parsel çevreleri toplamı

Çizelge 2. Proje alanındaki incelenen köylere ait maliklerin parsel durumu

\begin{tabular}{ccccccccccr}
\multirow{2}{*}{ Parsel } & TÖ & TS & TÖ & TS & TÖ & TS & TÖ & TS & TÖ & TS \\
\cline { 2 - 11 } Toplam & $(1)$ & $(1)$ & $(2-3)$ & $(2-3)$ & $(4-5)$ & $(4-5)$ & $(6-9)$ & $(6-9)$ & $(10+)$ & $(10+)$ \\
\cline { 2 - 11 } & 10871 & 16467 & 6351 & 5805 & 2715 & 1206 & 2281 & 379 & 2211 & 572 \\
\hline
\end{tabular}

Çizelge 3. Malik sayısının tüm malik sayısına göre yüzdelik durumu

\begin{tabular}{ccccccccccc}
\multirow{2}{*}{ Parsel } & TÖ & TS & TÖ & TS & TÖ & TS & TÖ & TS & TÖ & TS \\
\cline { 2 - 11 } & $(1)$ & $(1)$ & $(2-3)$ & $(2-3)$ & $(4-5)$ & $(4-5)$ & $(6-9)$ & $(6-9)$ & $(10+)$ & $(10+)$ \\
\cline { 2 - 11 } Ortalama \% & 44.50 & 67.41 & 26.00 & 23.76 & 11.11 & 4.94 & 9.34 & 1.55 & 9.05 & 2.34 \\
\hline
\end{tabular}

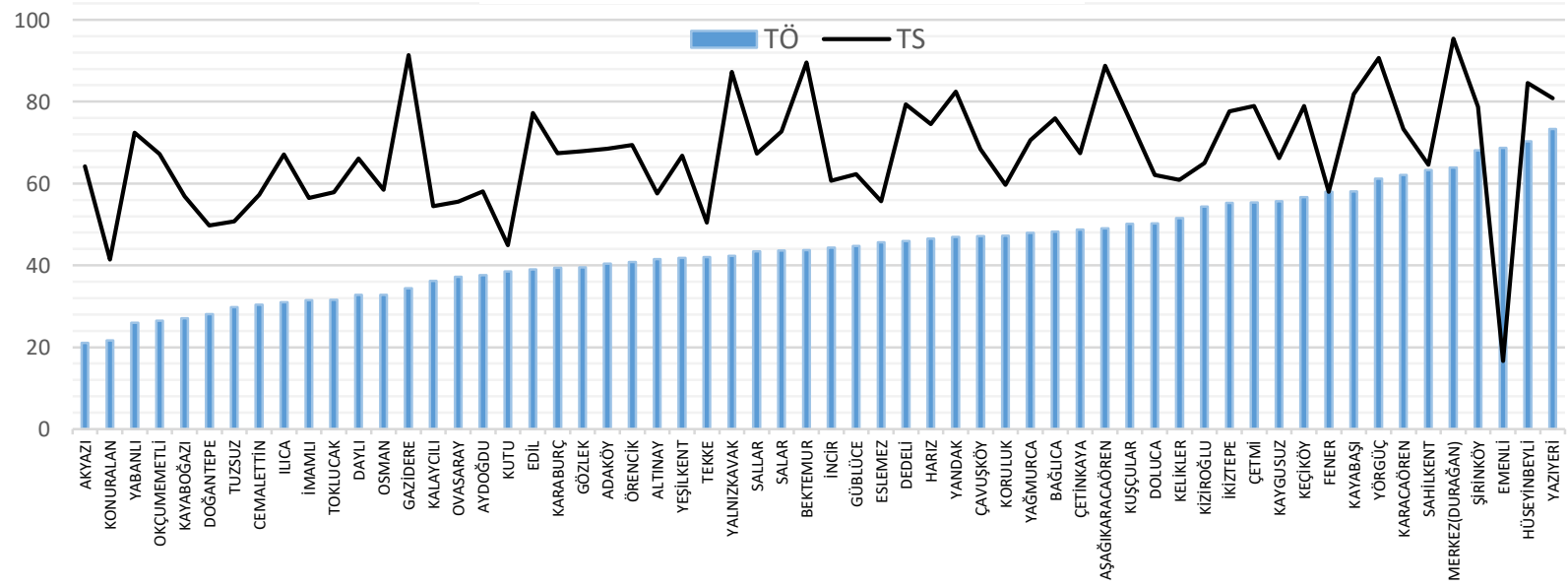

Şekil 5. 1 Hissesi bulunan maliklerin toplulaştırma öncesinde ve toplulaştırma sonrasında değişimi 


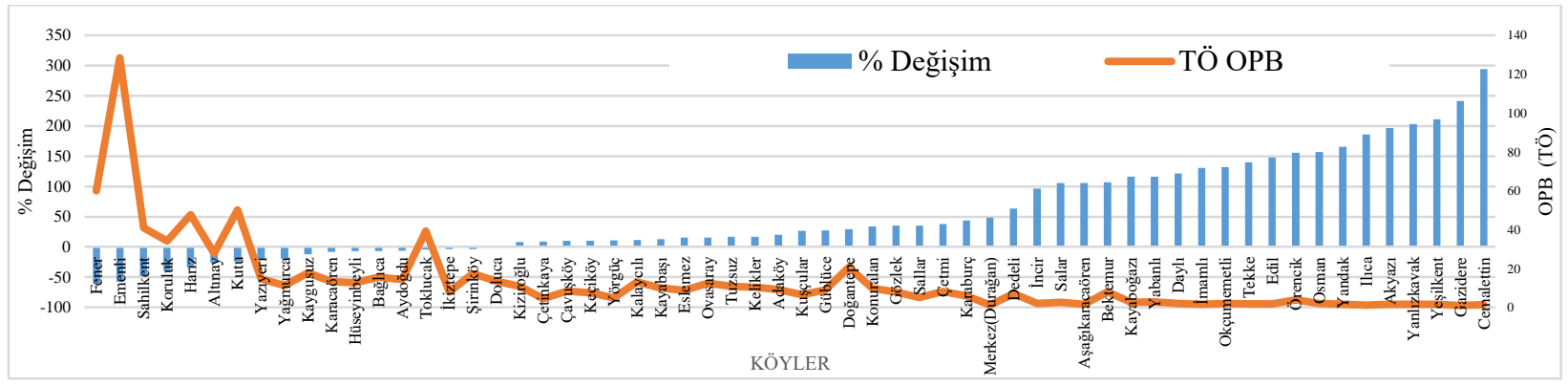

Şekil 6. OPB' nün TÖ’ sine göre \%’lik değişimi

\subsection{Malike Düşen Ortalama Parsel Adedi (MDOPA)}

Proje alanında 60 köy/mahalleye ait malike düşen ortalama parsel adedi toplulaştırma projesinden önce 1.25 iken toplulaştırma projesinden sonra 0.73 'e inmiştir.

\subsection{Malike Düşen Ortalama Hisse Sayısı (MDOHS)}

$60 \mathrm{köy} /$ mahallenin toplulaştırma projesinden önce MDOHS 3.88 iken toplulaştırmadan sonra 2.16'a düşmüştür. MDOHS değeri toplulaştırmadan sonra 1 veya 1'e yakın çıkması her malikin 1 parselde hissesi olmas1 anlamına gelmektedir. 60 köy/mahalledeki toplulaştırma sonrasında 2.16 çıkmıştır. Bu 60 köyden Emenli mahallesindeki toplulaştırma projesinden önce MDOHS 1.70 iken toplulaştırmadan sonra 20.61'e yükselmiştir. Bunun nedeni Emenli mahallesindeki hisse hatalı 7582 da yüzölçümlü 476 malikli 145 nolu parselden dolayı oluşmuştur. $\mathrm{Bu}$ parselde arazi maliklerin eskiden 1 parselde yeri varken toplulaştırma sonrasında 145 nolu parsel 26 farklı blokta planlandığından her malik içinde 26 blokta planlamasından kaynaklanmaktadır. Emenli mahallesi işleme katılmazsa MDOHS sayısı toplulaştırmadan önce 3.84 toplulaştırmadan sonra 1.62 olarak gerçekleşeceği hesaplanmıştır.

\subsection{Parsel Büyüklüğ̈ Saylss (PBS)}

Proje alanında 60 köy/mahalleye ait parsel büyüklüğü sayısı Çizelge 4'de gösterilmiştir.

Çizelge 4 incelendiğinde 60 köy/mahalleyi oluşturan toplulaştırmadan önceki 30475 parselin 7766 adedi 0-1 da aralığında parsellerden oluşmaktadır. 6086 adedi 1-2 da aralığında, 6831 adedi 2-5 da aralığında, 4409 adedi 5-10 da aralığında, 3812 adedi $10-25$ da aralığında, 1062 adedi $25-50$ da aralığında, 509 adedi $50+$ da aralığındadır. Toplulaştırmadan sonra oluşan 17901 parselin 924 adedi $0-1$ da aralığında parsellerden oluşmaktadır. 1502 adedi 1-2 da aralığında, 4459 adedi 2-5 da aralığında, 5010 adedi 5-10 da aralığında, 4313 adedi $10-25$ da aralığında, 1114 adedi $25-50$ da aralığında, 579 adedi $50+$ da aralığındadır.

Çizelge 4'de görüldüğü üzere 1 da'a kadar olan parseller çoğunluktadır. Buda parsellerin çok küçük ekonomik olarak işlenebilecek büyüklükten yoksun olduğunu göstermektedir. Küsek (2014) de benzer sonuçların oluştuğunu bildirmiştir.

Proje alanındaki incelenen köy/mahallelere ait parsel büyüklüğü sayısının yüzdelik oranı Çizelge 5 , de gösterilmiştir.

Çizelge 5 Proje alanındaki incelenen köy/mahallelere ait parsel büyüklüğü sayısının yüzdelik oranı incelendiğinde; Toplulaştırmadan önce 0-1 da aralığındaki parsel sayısı proje sahasında \% 25.5 iken toplulaştırmadan sonra \% 5.2 oranında gerçekleşmiştir. Benzer şekilde 1-2, 2-5, 5-10, 10-25, 25-50 ve 50 da üstü parsel sayıları sırasıyla toplulaştırmadan önce \% $20,22.4,14.5,12.5,3.5$ ve 1.7 iken toplulaştırmadan sonra ise bu rakamlar sirasiyla \% 8.4, 24.9, 28, 24.1, 6.2 ve 3.2 olarak gerçekleşmiştir (Şekil 7).

0-1 ve 1-2 da büyüklüklerinde düşüş gözlenirken diğer tüm aralıklarda artış gözlenmiştir. Artan aralıklarda artış oranı ortalama $\% 72$ olmuştur.

Çizelge 4. İncelenen projelere ait parsel büyüklüğü sayıları

\begin{tabular}{ccccccccccccccc} 
Alan (da) & TÖ & TS & TÖ & TS & TÖ & TS & TÖ & TS & TÖ & TS & TÖ & TS & TÖ & TS \\
\cline { 2 - 12 } & $0-1$ & $0-1$ & $1-2$ & $1-2$ & $2-5$ & $2-5$ & $5-10$ & $5-10$ & $10-25$ & $10-25$ & $25-50$ & $25-50$ & $50+$ & $50+$ \\
Toplam & 7766 & 924 & 6086 & 1502 & 6831 & 4459 & 4409 & 5010 & 3812 & 4313 & 1062 & 1114 & 509 & 579 \\
\hline
\end{tabular}

Çizelge 5. İncelenen projelere ait parsel büyüklüğü sayısının yüzdelik oranı

\begin{tabular}{|c|c|c|c|c|c|c|c|c|c|c|c|c|c|c|}
\hline \multirow{2}{*}{ Ala } & TÖ & $\Gamma S$ & TÖ & TS & TÖ & TS & TÖ & TS & TÖ & TS & TÖ & TS & TÖ & $\Gamma S$ \\
\hline & $0-1$ & $0-1$ & -2 & 2 & $2-5$ & 2- 5 & 10 & 10 & -25 & $0-25$ & $25-50$ & $5-50$ & $50+$ & $50+$ \\
\hline$\%$ & 25.5 & 5.2 & 20.0 & 8.4 & 22.4 & 24.9 & 14.5 & 28.0 & 12.5 & 24.1 & 3.5 & 6.2 & 1.7 & 3.2 \\
\hline
\end{tabular}




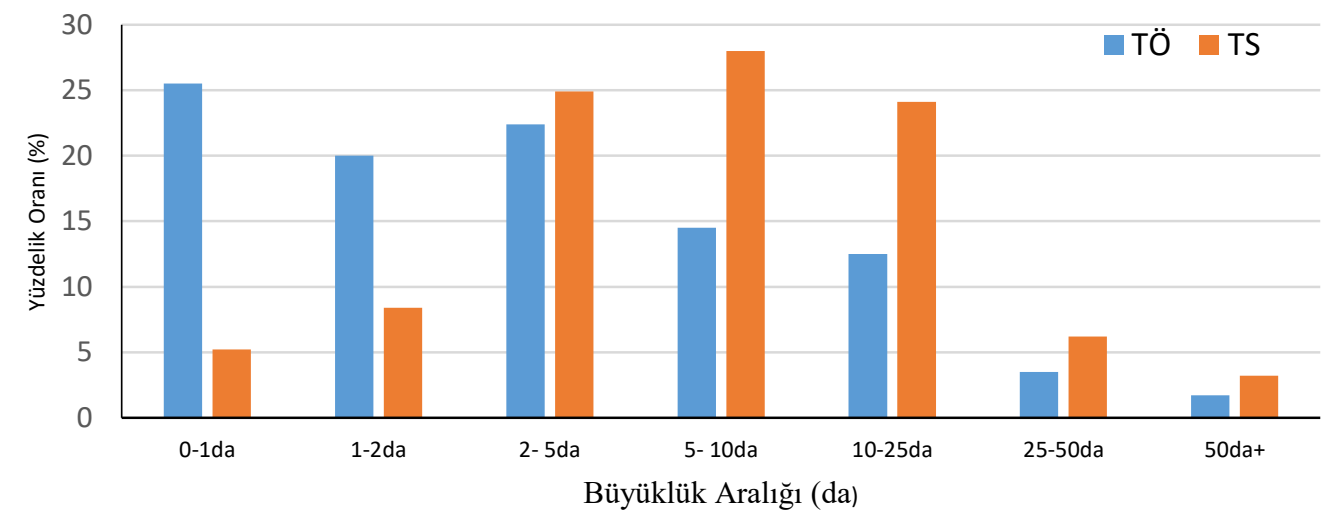

Şekil 7. İncelenen projelere ait parsel büyüklügü sayısının ortalama yüzdelik oranları

\subsection{Birim Çevre (BÇ)}

İncelenen 60 projede toplulaştırma öncesinde $\mathrm{BÇ}$ 40.84 iken toplulaştırma sonrasında 40.58 'e düşmüş ve birim çevrede $\% 0.6$ ' lik bir azalma meydana gelmiştir.

\subsection{Birim Alan Kaybu (BAK)}

Proje alanında 60 köy/mahalleye ait BAK Çizelge 6'da gösterilmiştir. Bu değerlerle arazi kazancı hesap edildiğinde parsel çevreleri toplamı farkı 1106244 m'dir. Her parselin sinırlarında $0.50 \mathrm{~cm}$ kullanılamadığından arazi kazanımı $0.50 * 1106244=553122 \mathrm{~m}^{2}$ olur. Tüm projeler dikkate alındığında kazanım oranı $\% 0.25$ olarak belirlenmiştir.

Kayı alan bakımından incelenen projelerin 17'sinde ortalama \% 15.6 artış gözlenirken, 43'ünde ise ortalama $\% 23.2$ azalma gözlenmiştir. Birim alan kaybında (BAK) ise 26 projede \% 24.2 artış bulunurken, 34 projede ise $\% 21.1$ düşüş gözlenmiştir.

\subsection{Parametrelerin Arasındaki Korelasyon Değerleri (PAKD)}

$60 \mathrm{köy} /$ mahalledeki incelenen parametrelerin korelasyon değerleri ve bu değerlere ait mutlak değer toplamları Çizelge 7'de verilmiştir.

Çizelge 7'de incelenen parametreler arasındaki korelasyon değerlerine bakıldığında 0.99 ile MDOPA ile PKMUT arasında çok kuvvetli ilişki mevcuttur. Korelasyon değerleri \% 85 ile $\% 100$ arasındaki değerlere bakıldığında ise TO ile OBP, BÇ, PÇT, MDOPA ve MDOHS arasında, TPS ile TPM, PÇT, PKMUT, MDOPA ve MDOHS arasında, PÇT ile BÇ, PKMUT, MDOPA ve BAK arasında, BÇ ile OPB ve BAK arasında, PKMUT ile MDOPA ve BAK arasında,
PKMUT ile MDOHS arasında, OPB ile BAK arasında ve MDOPA ile $B A K$ arasinda $\mathrm{p}<0.05$ seviyesinde kuvvetli ilişki mevcuttur.

Projedeki parametrelerin korelasyon değerlerinin mutlak değerleri alındığında 11.98 ile MDOPA en çok değer alan parametredir. Bundan sonra sirasıyla en çok mutlak değer alan parametreler PKMUT, TO, BAK, PÇT, TPS, BÇ, OPB, PBS, TPM, MKMUT, MDOHS, MPD, TPA, NST, ve HSTO dur.

60 projede yapılan araştırmada belirlenen kriterler arasında, (x) ve (y) değişkeni arasındaki korelasyondan yola çıkılarak kurulan regresyon modelleri Çizelge 8'de gibi elde edilmiştir:

Çizelge 7'de incelenen parametreler arasındaki korelasyon değerlerine bakıldığında 0.99 ile MDOPA ile PKMUT arasında çok kuvvetli ilişki mevcuttur. Korelasyon değerleri $\% 85$ ile $\% 100$ arasındaki değerlere bakıldığında ise TO ile OBP, BÇ, PÇT, MDOPA ve MDOHS arasında, TPS ile TPM, PÇT, PKMUT, MDOPA ve MDOHS arasında, PÇT ile BÇ, PKMUT, MDOPA ve BAK arasında, BÇ ile OPB ve BAK arasinda, PKMUT ile MDOPA ve BAK arasinda, PKMUT ile MDOHS arasinda, OPB ile BAK arasinda ve MDOPA ile $B A K$ arasinda $\mathrm{p}<0.05$ seviyesinde kuvvetli ilişsi mevcuttur.

Projedeki parametrelerin korelasyon değerlerinin mutlak değerleri alındığında 11.98 ile MDOPA en çok değer alan parametredir. Bundan sonra sırasıyla en çok mutlak değer alan parametreler PKMUT, TO, BAK, PÇT, TPS, BÇ, OPB, PBS, TPM, MKMUT, MDOHS, MPD, TPA, NST, ve HSTO dur.

60 projede yapılan araştırmada belirlenen kriterler arasında, (x) ve (y) değişkeni arasındaki korelasyondan yola çıkılarak kurulan regresyon modelleri Çizelge 8 'deki gibi elde edilmiştir. 
Çizelge 6. İncelenen projelere ait Birim Alan Kayb1

\begin{tabular}{|c|c|c|c|c|c|c|c|c|}
\hline & TÖ & $\mathrm{TS}$ & TÖ & TS & TÖ & $\mathrm{TS}$ & TÖ & $\mathrm{TS}$ \\
\hline & PÇT & PÇT & Alan & Alan & Kayıp & Kayıp & BAK & BAK \\
\hline Toplam & 9994307 & 8888062 & 244699 & 219041 & 4997.15 & 4444.03 & 20.42 & 20.29 \\
\hline
\end{tabular}

Çizelge 7. İncelenen parametrelerin arasındaki korelasyon değerleri

\begin{tabular}{|c|c|c|c|c|c|c|c|c|c|c|c|c|c|c|c|c|}
\hline TO & $\begin{array}{r}\text { TO } \\
1\end{array}$ & TPS & TPA & TPMS & HSTO & PÇT & $\mathrm{BÇ}$ & PKMUT & MKMUT & NST & OPB & MDOPA & MDOHS & BAK & PBS & MPD \\
\hline TPS & 0.81 & 1 & & & & & & & & & & & & & & \\
\hline TPA & 0.45 & 0.73 & 1 & & & & & & & & & & & & & \\
\hline TPMS & 0.80 & 0.89 & 0.77 & 1 & & & & & & & & & & & & \\
\hline HSTO & 0.49 & 0.21 & 0.05 & 0.24 & 1 & & & & & & & & & & & \\
\hline PÇT & 0.87 & 0.87 & 0.60 & 0.76 & 0.27 & 1 & & & & & & & & & & \\
\hline$\overline{B C ̧}$ & -0.94 & -0.74 & -0.35 & -0.70 & -0.43 & -0.88 & 1 & & & & & & & & & \\
\hline PKMUT & 0.87 & 0.96 & 0.61 & 0.84 & 0.24 & 0.92 & -0.82 & 1 & & & & & & & & \\
\hline MKMUT & 0.67 & 0.50 & 0.07 & 0.32 & 0.40 & 0.66 & -0.67 & 0.63 & 1 & & & & & & & \\
\hline NST & 0.47 & 0.50 & 0.40 & 0.58 & 0.16 & 0.44 & -0.45 & 0.46 & 0.10 & 1 & & & & & & \\
\hline OPB & -0.96 & -0.72 & -0.29 & -0.71 & -0.51 & -0.77 & 0.95 & -0.79 & -0.66 & -0.46 & 1 & & & & & \\
\hline MDOPA & 0.88 & 0.96 & 0.61 & 0.83 & 0.25 & 0.93 & -0.82 & 0.99 & 0.65 & 0.45 & -0.80 & 1 & & & & \\
\hline MDOHS & 0.62 & 0.44 & 0.04 & 0.26 & 0.37 & 0.63 & -0.63 & 0.57 & 0.98 & 0.08 & -0.61 & 0.60 & 1 & & & \\
\hline BAK & 0.90 & 0.85 & 0.48 & 0.72 & 0.31 & 0.97 & -0.93 & 0.92 & 0.72 & 0.43 & -0.86 & 0.93 & 0.69 & 1 & & \\
\hline PBS & 0.67 & 0.74 & 0.33 & 0.56 & 0.22 & 0.68 & -0.64 & 0.80 & 0.55 & 0.20 & -0.63 & 0.79 & 0.49 & 0.71 & 1 & \\
\hline MPD & 0.45 & 0.42 & 0.23 & 0.41 & 0.16 & 0.45 & -0.37 & 0.49 & 0.41 & 0.13 & -0.40 & 0.50 & 0.34 & 0.42 & 0.43 & 1 \\
\hline Mutlak Top & 11.85 & 11.34 & 7.01 & 10.38 & 5.33 & 11.70 & 11.31 & 11.91 & 9.00 & 6.30 & 11.12 & 11.98 & 8.36 & 11.81 & 10.44 & 60 \\
\hline
\end{tabular}

Koyu değerler $\mathrm{p}<0.05$ düzeyinde önemli.

Çizelge 8. Proje değerlerine göre regresyon modelleri

\begin{tabular}{|c|c|c|c|}
\hline Formüller & $\mathrm{R}^{2}$ & Formüller & $\mathrm{R}^{2}$ \\
\hline $\mathrm{TO}=-72.013 \times \mathrm{xOBP}+86.587$ & 0.9235 & $\mathrm{PÇT}=0.3217 \mathrm{xPKMUT}+0.6836$ & 0.8502 \\
\hline $\mathrm{TO}=-112.36 \mathrm{xBÇ}+136.52$ & 0.8767 & $\mathrm{PÇT}=0.3341 \times \mathrm{xMOPA}+0.6453$ & 0.8688 \\
\hline $\mathrm{TO}=102.49 \times \mathrm{xBAK}-86.686$ & 0.8068 & $\mathrm{PÇT}=0.9954 \times \mathrm{BAK}+0.1214$ & 0.9377 \\
\hline $\mathrm{TO}=96.901 \times \mathrm{PÇT}-91.829$ & 0.7620 & $\mathrm{BC}=0.5938 \mathrm{xOPB}+0.4841$ & 0.9024 \\
\hline $\mathrm{TO}=33.718 \mathrm{xPKMUT}-29.786$ & 0.7581 & $\mathrm{BÇ}=-0.8877 \times \mathrm{xBAK}+1.9604$ & 0.8735 \\
\hline $\mathrm{TO}=34.88 \mathrm{x}$ MDOPA- 33.566 & 0.7684 & $\mathrm{PKMUT}=1.0152 \times \mathrm{xMDOPA}-0.0794$ & 0.9762 \\
\hline $\mathrm{TPS}=2.3924 \mathrm{xTPM}-0.6816$ & 0.7956 & $\mathrm{PKMUT}=2.7009 \times \mathrm{xAK}-1.3157$ & 0.8402 \\
\hline $\mathrm{TPS}=1.1728 \mathrm{xPKMUT}-0.358$ & 0.9179 & $\mathrm{MKMUT}=0.8714 \times \mathrm{xMOHS}+0.211$ & 0.9594 \\
\hline $\mathrm{TPS}=1.2105 \mathrm{xMDOPA}-0.485$ & 0.9262 & $\mathrm{MDOPA}=2.6539 \mathrm{x}-1.2105$ & 0.8564 \\
\hline
\end{tabular}

Çizelge 8'nin ilk denklemi TO $=-72.013 \times$ OPB + 86.587 için bir projede OPB oranı belirlenerek denklemde yerine konulduğunda TO bulunabilir. OPB oranı 1 olan bir proje sahasında TO'nın 14.57 olacağ $\% 92.35$ oranında tanımlanabilecek şekilde söylenebilir. TO'nın bu rakamdan daha yüksek çıkması OPB nin normalden daha yüksek oluşturulmasının başarıldığı anlamına gelirken daha düşük çıkması ise OPB'nin normalin altına düştüğü anlamına geldiği söylenebilir.

Peker ve Dağdelen (2016)'in yaptığ 1 çalışmada, toplulaştırmadan önceki ve sonraki ortalama parsel büyüklükleri sırasıyla 5.18 ve 9.28 da olarak bildirilmiş ve de toplulaştırma oranı ise \% 44 olarak belirlenmiştir. $\mathrm{Bu}$ değerler kullanılarak OPB oranı (5.18/9.28) olan 0.558 değeri $\mathrm{TO}=-72.013 \mathrm{OBP}-86.587$ denkleminde yerine konduğunda $\mathrm{TO}=\% 46.4$ gibi bir değerin elde edilmesi çalışmayı destekler niteliktedir.

\subsection{Projelerin Performans Değerleri}

İncelenen $60 \mathrm{köy} /$ mahalledeki projelerin performans değerleri Çizelge 9'da verilmiştir.

Çizelge 9 incelendiğinde çalışma yapılan 60 köy/mahallenin performansı ortalama olarak \% 76.3 olarak ortaya çıkmıştır.

Şekil 8'de 60 projenin 25 parametreye göre 100 üzerinden aldığı performans puanları grafik olarak gösterilmiştir.

Köy bazında performans olarak en düşük \% 24 ile Sahilkent mahallesi, en yüksek \% 96 ile Adaköy mahallesi, Akyazı, Tuzsuz ve Konuralan köyleri olduğu görülmektedir.

Şekil 9'da Projelerde performansı değerlendirirken kullanilan parametrelerin 60 projedeki durumu 
gösterilmiştir.

Şekil 9 incelendiğinde projeleri değerlendirirken kullanılan parametrelerin performansa etkili etki ettiği miktarlar görülmektedir. Buna göre en fazla etki eden parametreler 58 köy/mahallede HSTO, MKMUT, MDOPS, MPD (1 Parsel) ve MPD (6-9 parsel), en az etki eden parametre ise $26 \mathrm{köy} /$ mahallede MPD (2-3 parsel)'dir.

Çizelge 9. Projelerin performans değerleri

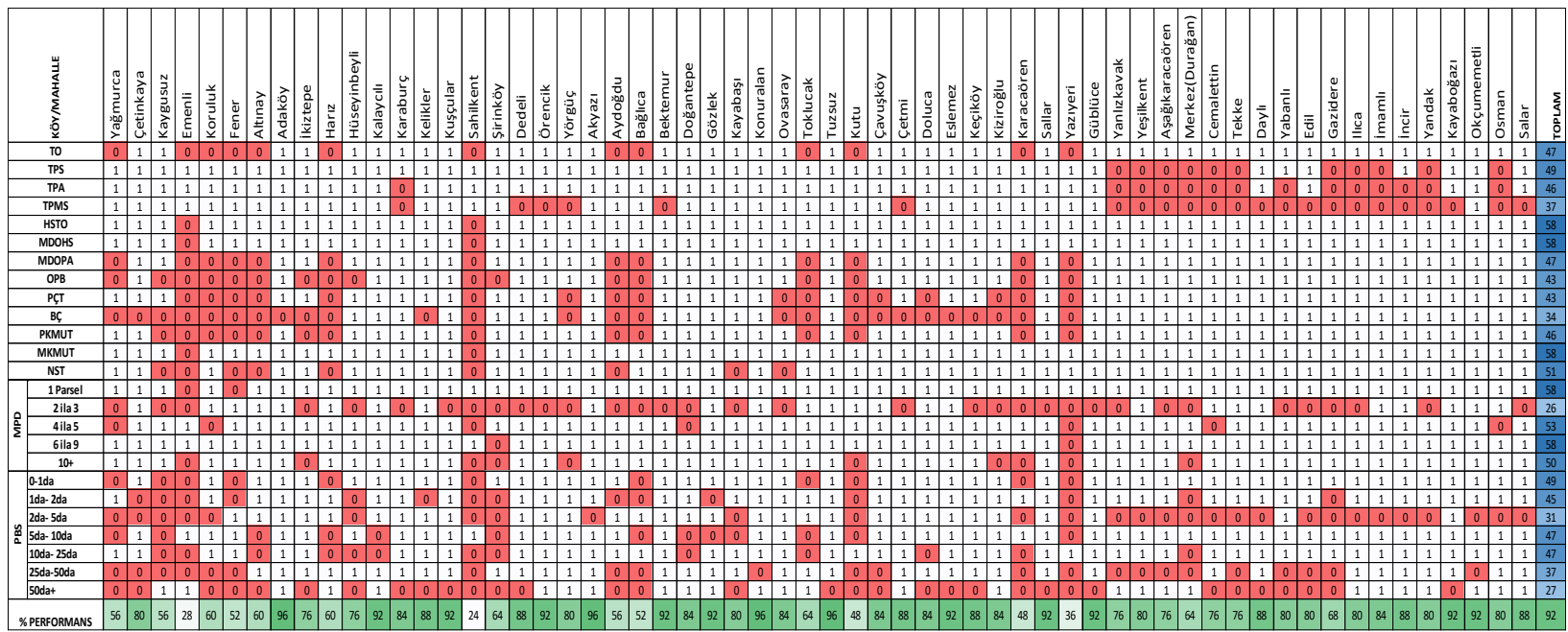

\% PERFORMANS

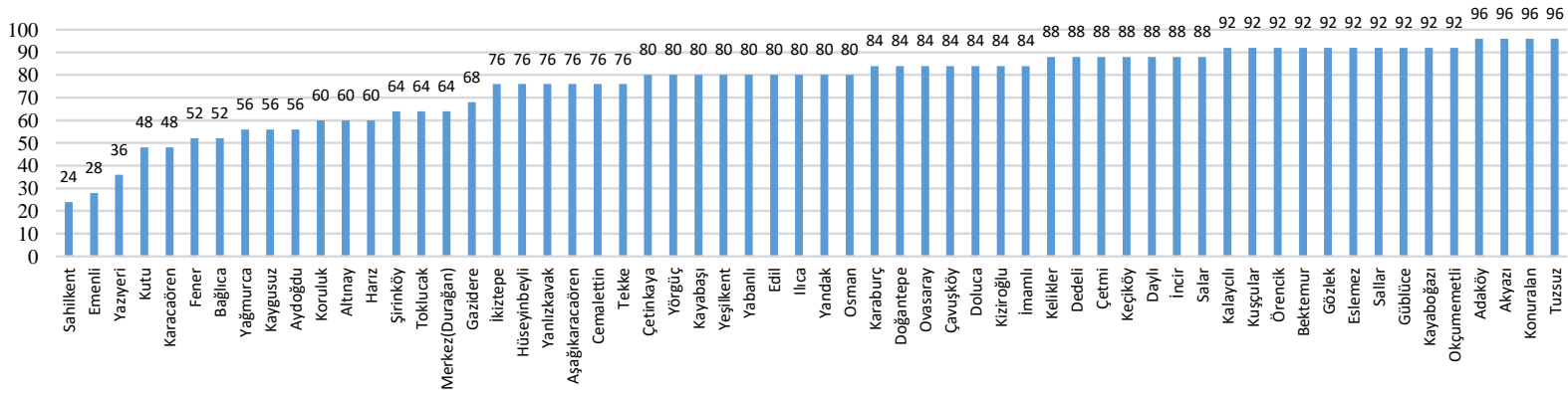

Şekil 8. Projelerin performans değerleri

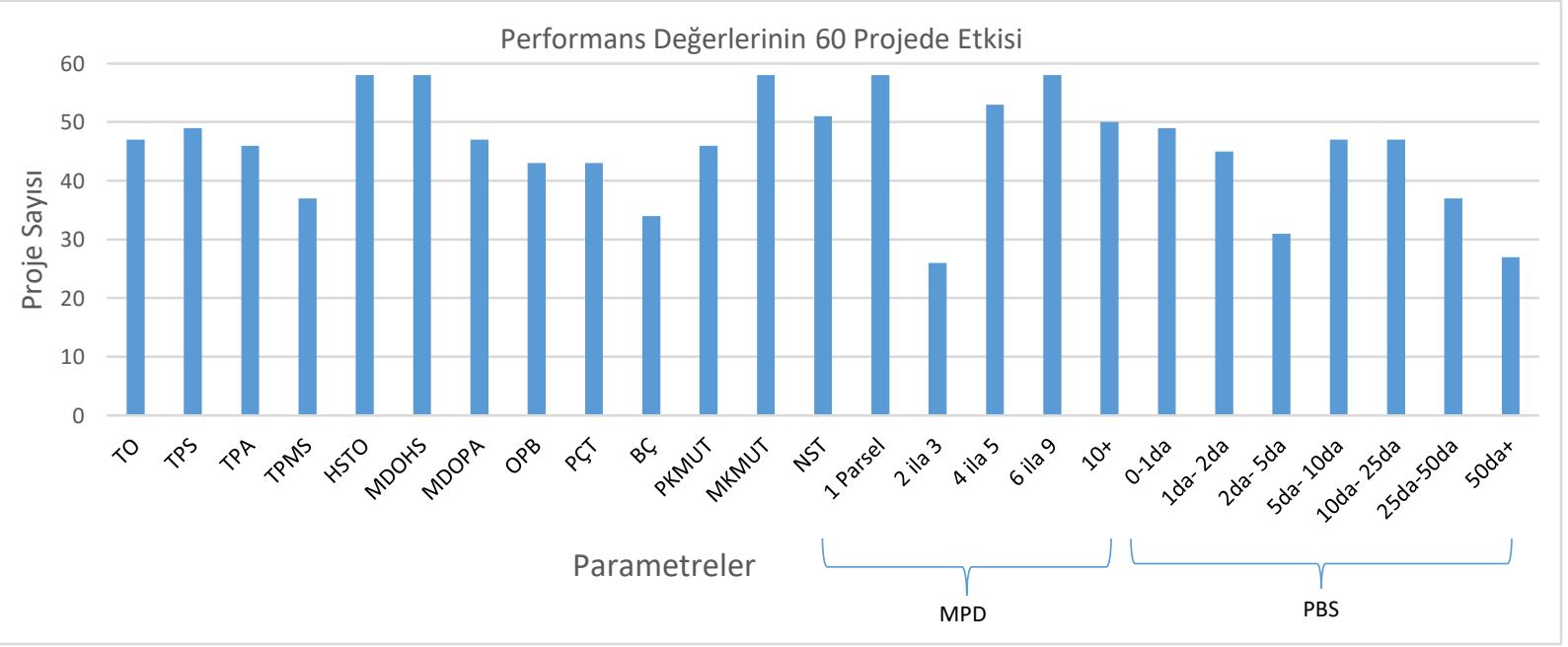

Şekil 9. Performans değerlerinin 60 projede etkisi 


\section{Sonuç}

Araştırma alanı için arazi toplulaştırmada başarı ölçütü olarak parsel sayısı dikkate alındığında; 47 yerleşim yerinde azalma, 13 yerleşim yerinde ise artma gözlenmiştir. Arazi toplulaştırma projelerinin farklı açılardan incelenmesi, toplulaştırma oranının hesaplanmasında parsel sayısı üzerinden gidilmesinin yeterli olmadığı sonucunu ortaya koymaktadır. Bu nedenle bu çalışmada ilave olarak parseldeki hisse sayılarından yola çıkarılarak toplulaştırmanın oranı tekrar hesaplanmıştır. Toplulaştırma yapılan alanlarda malikler müştereklikten kurtulmak için tercihlerini müstakil parsel yönünde kullandığından parsel sayısında artış meydana gelmektedir. $\mathrm{Bu}$ da parsel sayısı üzerinden toplulaştırma oranını negatif değer yaparken hisse sayısı üzerinden yapılan toplulaştırma oranı pozitif değer çıkmaktadır. Hisse sayısı üzerinden toplulaştırma oranının hesaplanması daha doğru ve güvenilir sonuç alınabilir.

Ülkemizde arazi mülkiyeti çok önemli bir değerdir. $\mathrm{Bu}$ nedenle varisler ve komşular arasında süregelen mülkiyet anlaşmazlıkları sosyal huzurun bozulmasında yerel yönetim ve yargı kuruluşlarına sı sık başvurulmasında başlıca etkenler olarak gösterilmektedir. Arazi toplulaştırması bu tür anlaşmazlıkların bir bölümünün ortadan kaldırılmasında veya tamamen çözümlenmesinde ve dolayısıyla sosyal huzurun nispeten sağlanmasında etkili bir rol oynamaktadır. Maliklerin arazi toplulaştırma yapılırken tercihini tam parsel olarak planlamayı veya bir işletme olacak şekilde planlamayı talep etmektedir. İncelenen köy/mahallelerde tam parsel oluşumunda önemli artış mevcuttur. Toplulaştırma öncesine göre tam parsel sayısında azalmalar genelde ekonomik olarak kullanılmaya uygun olmayan çok küçük parsellerin birleştirilmesi nedeniyle tam parsel sayılarında azalma meydana gelmiştir.

Tarım yapılan alanlarda çit veya tarla sınırına yaklaşamama nedeniyle, tarla sınırına paralel en az 50 $\mathrm{cm}$ genişliğindeki bir tarla şeridi tam anlamıyla ekilemez. Bu ise bir kısım alanın boş kalmasına veya ürün kaybına neden olur. Arazi toplulaştırması yapılan sahalarda sınır kayıplarının en az olması açısından en elverişli parsel şekli kare, İşleme kolaylığı ve zaman kaybının önlenmesi açısından ise dikdörtgen, parsellerdir. Parsellerin şekillerinin bozuk oluşu tarlanın sürümü sırasında çiftçiye güçlük yaratmakta, sürülme zamanını artırarak, zaman kayıplarına neden olmaktadır. Arazi toplulaştırma uygulamaları yapılan parsellerin şekilleri genel olarak dikdörtgenlerden oluşmaktadır. Şekilleri düzgün olan tarlalarda insan ve makinelerin veriminde önemli artışlar sağlanmaktadır. Ayrıca tarım makinelerinin kullanımı kolaylaşmakta, işleme maliyetleri ve süreleri azalmaktadır. Toplulaştırma projesinin öncesinde parsellerin çoğu şekilsiz olması nedeniyle parsel çevresi ve nokta kırık sayısı ve çevre uzunluğu fazladır. Toplulaştırma sonrasında dikdörtgen parseller oluşması istendiğinden çevre uzunluğunda $\% 11$ ve kırık nokta sayısında \% 47 oranında azalmıştır

Arazi toplulaştırma çalışmalarında planlanan, önemli olgulardan biriside, tarım arazileri içerisinde altyapısı tamamlanmış yolların yapılarak, ulaşımın ekonomik ve kolay hale getirilmesi işlemleridir. Maliklerin yerleşme alanları ile tarımsal arazilerine ulaşması için kat edilmesi gereken yol toplulaştırma projesi ile hisse sayısı ve parsel sayısı azaldığından yol mesafesi azalmakta ve böylece çiftçilerin gidiş geliş için harcadığı zaman ve yakıttan tasarruf edilmektedir. Çalışılan proje sahasında parsel bazında ve parsellerdeki malik bazında köy merkezine uzaklıklarda yoldan \% 64 oranında azalması nedeniyle zaman ve yakıttan kazanım sağlanmıştır.

Proje sahasında toplulaştırma öncesinde tüm parsellerin yolu mevcut değildir. Parsel mülkiyetindeki müştereklikten dolayı işletmeler kendi aralarında rızai taksim yaparak oluşturdukları parsellere ulaşmak için ayrıca yol planladığından, arazi kayıplarına neden olmaktadır. Proje sahasında toplulaştırma öncesinde yolsuz parseller mevcut iken toplulaştırma sonrasında yolsuz parsel oluşturulamayacağından tamamı yola kavuşturulmuştur.

Maliklerin parselleri çok küçük olduğunda, yani tarladaki iş, 1 iş gününü doldurmadığ 1 veya sık sık tarla değiştirilmesi tarımsal araziye gidiş geliş ve aletlerin tekrar toplanması nedeniyle işgücü verimli bir şekilde değerlendirilememekte ve zaman kaybına neden olmaktadır. Dağınık haldeki parsellerde alet ve makinelerin rasyonel kullanımını da zorlaştırmaktadır. Toplulaştırma ile malikler parseldeki hisselerini birleştirmekle daha büyük parseller oluşmakta, maliklerin birden çok parseldeki hisselerini de büyük bir çoğunlukta müstakil talep etmektedir. Parsel oluşturacak kadar hissesi bulunmayan malikler de tüm parsellerdeki hisselerini bir işletme olabilecek maliklerle tek parselde birleştirerek daha kullanılabilir parseller oluşturmuştur. Çalışma alanında toplulaştırmadan önce OPB 8.03 iken toplulaştırmadan sonra 12.24 olmuştur. TPS'da \% 35 azalma, TPA ve TPMS'da sirasiyla \% 18.53 ve $\% 8,91$ artış meydana gelmiştir.

Toplulaştırma yapılmayan alanlarda devletçe uygulanan sulama projelerinde tarım arazilerinde kanal ve kanalet tesisi mülkiyet ve parsel sınırları gözetilerek planlandığından mühendislik ve optimum şartlardan uzaklaşmaktadır. $\mathrm{Bu}$ da sulama projelerinde yapılan kanal uzunluğu ve sanat yapıları miktarını arttırdığından hem maliyet hem de sulama randımanını düşürmektedir.

Arazi toplulaştırma projelerinde başarıyı yakalamak için projelerin değerlendirilmesinde kullanılacak başarı kriterlerinin belirlenmesi ve her bir projede bu başarı kriterlerinde belirlenen oranlardan daha yüksek başarıyı sağlayanlara onay verilecek şekilde gerekli yönetmeliklerin yeniden gözden geçirilerek toplulaştırmanın daha verimli hale getirilmesi daha uygun olacaktır. 


\section{Kaynaklar}

Anonim, 2000. DPT, VIII. Beş yıllık kalkınma planı (20012005). Arazi Kullanımı, Arazi ve Arsa Politikaları ve Arazi Toplulaştırması Alt Komisyonu Raporu, 17 Ocak, Ankara.

Arıcı, İ., 1994. Arazi toplulaştırması. Uludağ Üniversitesi Ziraat Fakültesi Ders Notları, No:60, Bursa, 121s.

Arslan, H., Tunca, E., 2013. Arazi toplulaştırmasının sulama projelerinin performansı üzerine etkileri. Anadolu Tarım Bilim. Derg., 2013,28(3):126-133.

Bayraç, N., Yenilmez, F., 2006. Tarım sektörünün yapısal analizi ve avrupa ortak tarım politikası. www.econturk.org /Türkiyeekonomisi/Naci2.doc (Erişim Tarihi: 07.03.2010)

Boyacıoğlu, R., 1973. Arazi toplulaştırması yapılan erzincan güllüce köyündeki tarımsal işletmelerin ekonomik analizi, 131 s., Erzincan.

Boyraz, Z. ve Üstündağ, Ö., 2008. Kırsal alanlarda arazi toplulaştırma çalışmalarının önemi. e-Journal of New World Sciences Academy. Volume: 3, Number: 3.
Boztoprak, T., Demir O., Coruhlu Y. E., 2016. Comparison of expropriation and land consolidation on the regulation of agricultural land. Sigma J Eng \& Nat Sci 34 (1), 2016, 43-55.

Ekinci, K., 2012. Samsun ili bafra ovası arazi toplulaştırması projesinde çiftçi davranışlarının belirlenmesi ve projenin sosyo-ekonomik yararları. Yüksek Lisans Tezi. Gaziosmanpaşa Üniversitesi Fen Bilimleri Enstitüsü. Tokat.

Küsek, G., 2014. Sulama Projeleri İçin Arazi Toplulaştırmasının Tekno-Ekonomik Değerlendirmesi. Ç.Ü.Z.F. Dergisi, 2014, 29 (1) : 7-20.

Peker, M., Dağdelen, N. 2016. Aydın bölgesi toplulaştırma sahalarında toplulaştırma öncesi ve sonrası kültürteknik hizmetlerinin irdelenmesi. Adnan Menderes Üniversitesi Ziraat Fakültesi Dergisi. 13(1):25-33

Takka, S., 1988. Türkiye'de arazi toplulaştırmasının önemi, sulama projelerinde sağladığı faydalar ve toplulaştırmayı gerektiren nedenler; toplulaştırma uygulamaları ve kanuni mevzuat. Sulama Projelerinde Arazi Toplulaştırması Semineri Bildirileri 